\title{
Inquietações de um viajante no apogeu do stalinismo
}

\author{
[ Restlessness of a traveler in the pinnacle of stalinism
}

\section{Fabio Cesar Alves ${ }^{\mathrm{I}}$}

RESUMO-Este artigo pretende analisar o relato da viagem que Graciliano Ramos fez à União Soviética e democracias populares no início da década de I950. Para isso, leva em conta tanto os traços da realidade observada quanto as reações do próprio diarista, de modo a entender como o escritor militante foi capaz de criar uma forma literária que põe em discussão, indiretamente, aspectos cruciais da autocracia stalinista, à época impulsionada pela vitória na Segunda Guerra Mundial e pelo IV Plano Quinquenal. O ensaio recupera também parte da recepção crítica imediata da obra publicada em I954 a fim de embasar as análises apresentadas. • PALAVRAS-CHAVE-Graciliano Ramos; Viagem; União Soviética; Stalin; Partido Comunista Brasileiro. • ABSTRACT - This article intends to analyze the accounting of the trip Graciliano Ramos took to the Soviet Union and popular democracies in the beginning of the I950s. In order to do so, it takes into account both the traces of reality observed and the reactions of the writer himself in order to understand how the militant author was able to create a form which places under discussion, indirectly, key aspects of the stalinist autocracry, which, at the time, boosted by the victory in the postwar, saw its pinnacle. The essay also recovers part of the critical reception immediately after the work was published in I954, in the interest of laying the foundation for the analysis presented. KEYWORDS - Graciliano Ramos; Viagem; Soviet Union; Stalin; Brazilian Communist Party.

Recebido em 29 de setembro de 2017

Aprovado em Io de agosto de 2018

ALVES, Fabio Cesar. Inquietações de um viajante no apogeu do stalinismo. Revista do Instituto de Estudos Brasileiros, Brasil, n. 70, p. 270-290, ago. 2018.

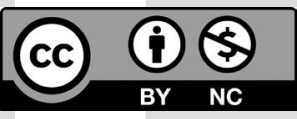

DOI: http://dx.doi.org/Io.II606/issn.23I6-90IX.voi70p270-290

I Universidade de São Paulo (USP, São Paulo, SP, Brasil). 


\section{Para Bruno Barreto Gomide e Homero Freitas de Andrade}

Esperavam de mim, com certeza, julgamentos de conjunto. Como explicar que ao mesmo tempo, na URSS, sentira (moralmente) tanto calor e tanto frio? (André Gide, De volta da

URSS, 1937)

Certo travo amargo perpassa uma primeira leitura de Viagem, de Graciliano Ramos, publicado postumamente em I $954^{2}$. Muito dessa sensação deriva do fato de que, em lugar de uma visão nítida da autocracia stalinista, que poderia corroborar a imagem sem frinchas do escritor sempre lúcido, encontramos em diversas passagens do livro considerável grau de fascínio do intelectual militante pela realidade soviética, àquela altura rechaçada apenas pela esquerda não alinhada ao então Partido Comunista do Brasil (PCB) ${ }^{3}$. No entanto, o mesmo relato, se paga preito à ideologia da época e da agremiação política à qual o escritor filiou-se em I945, a convite de Luís Carlos Prestes, também aponta, por meio da elaboração formal e à revelia das intenções do autor, para uma representação que destoa dos registros de viagem de muitos

2 Edição utilizada: Ramos, 2007.

3 A Oposição de Esquerda, no Brasil liderada por Mário Pedrosa e Lívio Xavier, denunciava, no final dos I920, o “culto à personalidade” de Stalin, e o precário conhecimento, pela Internacional Comunista (IC), das "estruturas econômico-sociais do Brasil" (MARQUES NETO, I993, p. I40-I4I). Por sua vez, o crítico Paulo Emilio Sales Gomes, em entrevista de I945, constatava, a despeito da vitória na Segunda Guerra Mundial e do prestígio dela consequente, que as gerações mais novas já deixavam de ver a "Mãe Rússia” como referência central (NEME, I945, p. 289). 
de seus contemporâneos4. Como se sabe, Graciliano viajou nos primeiros meses de 1952 para a União Soviética e as chamadas “democracias populares” do leste europeu (Tchecoslováquia e Geórgia), a convite do Comitê Central do PCB, como parte de uma delegação encarregada de acompanhar os festejos do Primeiro de Maio, grupo que incluía o senador Abel Chermont, o jornalista Moacir Werneck de Castro e o pianista Arnaldo Estrella. Àquela altura, o escritor exercia também a função de presidente da Associação Brasileira de Escritores (ABDE), entidade que desempenhou um papel crucial na luta contra a ditadura varguista, mas que desde o fim dos anos I940 encontrava-se inteiramente aparelhada pelos comunistas 5 .

O interesse declarado de Graciliano pela realidade soviética é, porém, muito anterior à viagem. Em crônica de I945, o escritor faz um breve histórico sobre a URSS e comenta a atração que o país exercia sobre sua sensibilidade, desde a Revolução de I9I7 ("pouco a pouco nos habituamos à ideia de que o movimento podia alargar-se, aprofundar-se e dar trabalho ao mundo capitalista”) à vitória na Segunda Guerra Mundial contra o nazifascismo ("numerosas epopeias, Stalingrado, Leningrado, Berlim e a derrota fragorosa do mais terrível dos inimigos"). Protestando contra "as contradições, mentiras e calúnias estúpidas" das agências de notícias que desde a revolução difundiam injúrias de toda ordem, o cronista conclui que havia sido necessário "o sacrifício de doze milhões de trabalhadores soviéticos para que chegasse convicção e terror ao espírito desses miseráveis que só acreditam na força bruta”. A incontida posição política diante da "guerra total" aparece, na crônica, acompanhada de um diagnóstico sobre o poderio soviético que, pouco depois, seria potencializado pela "cortina de ferro" anunciada por Winston Churchill, em I946, e pelo início da Guerra Fria no ano seguinte, quando a coexistência pacífica tornou-se expediente tático para a corrida armamentista e para a disputa de áreas de influência.

4 É o caso do relato de Astrojildo Pereira, publicado em I934, no qual o fundador do PCB discorre sobre as realizações do I Plano Quinquenal, lideradas por um governo "saído das massas" e que "se confunde com as massas" (PEREIRA, I985, p. 50). Jorge Amado, em I95I, publicou obra em que descreve Stalin como "mestre, guia e pai”, sendo o líder “a personificação da própria revolução", e a URSS como um lugar "onde cresce um homem novo e melhor" (AMADO, I954, p. 234). Também a jornalista e escritora Eneida de Moraes, ex-companheira de prisão de Graciliano, viajou à União Soviética em I959, e relata que, nas três semanas de visitas, "viu tudo o que quis", caminhando "de encantamento a encantamento" (MORAES, I959, p. 34).

5 Sobre a importância da ABDE na luta contra o Estado Novo e pela profissionalização dos escritores, ver: Lima, 2010.

6 "Revolução Russa" (RAMOS, 20I2, p. 24I-243). 


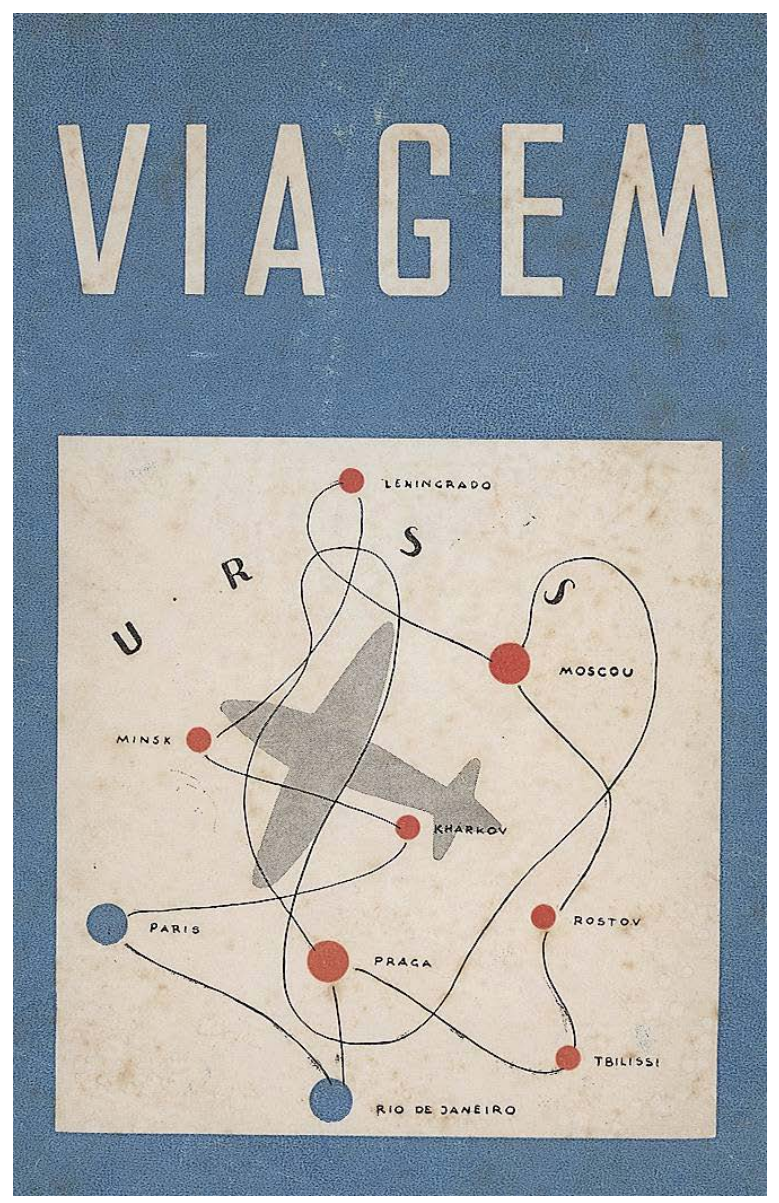

Figura I - Ilustração de Candido Portinari, “Avião”, para a primeira edição de Viagem (I954). Acervo do Projeto Portinari. Referência: FCO 4852

Em Viagem, assim como na crônica, há o discurso desmistificador com relação às informações veiculadas pelas agências burguesas, em um novo contexto de polarização máxima e quando o stalinismo, impulsionado pela vitória na Segunda Guerra Mundial e pelas altas taxas de industrialização decorrentes do IV Plano Quinquenal, vivia o auge de seu prestígio (REIS, 2002, p. I69). Graciliano critica, logo nas primeiras páginas do diário, a adesão ingênua ao que era propalado pelos órgãos de imprensa dos países capitalistas: a "extrema dedicação [dos guias] abriu-me portas que, entre nós, tipos bem-intencionados, obedientes ao jornal e ao sermão, consideram de ferro" (RAMOS, 2007, p. II). Mas a euforia demonstrada na crônica quando da vitória dos Aliados dá lugar, sete anos depois, a dúvidas sobre o que o viajante viu e como as suas impressões deveriam ser registradas, ponderações sobre a 
vida soviética que fogem da assertividade7. Tais questionamentos aparecem, de forma embrionária, ainda no capítulo de abertura, espécie de carta de intenções da obra:

Em abril de I952 embrenhei-me numa aventura singular: fui a Moscou e a outros lugares medonhos situados além da cortina de ferro exposta com vigor pela civilização cristã e ocidental [...]. Absurda semelhante viagem - e quando me trataram dela, quase me zanguei. Faltavam-me recursos para realizá-la; a experiência me afirmava que não me deixariam sair do Brasil; e, para falar com franqueza, não me sentia disposto a mexer-me, abandonar a toca onde vivo. [...] Estava decidido a não viajar; e, em consequência da firme decisão, encontrei-me um dia metido na encrenca voadora, o cinto amarrado, os cigarros inúteis, em obediência ao letreiro exigente aceso à porta da cabina. [...] Em terra, a convivência obrigatória com pessoas de raças diferentes da minha, de hábitos diferentes dos meus, e a necessidade forte de entendê-las, às vezes recorrendo a três intérpretes. Na passagem de uma língua para outra, o pensamento se modificava - e era-me preciso examinar as fisionomias, buscar saber o que se encerrava em almas exóticas. A palavra não raro nos enganava, e um gesto, um olhar, um sorriso, de repente nos surgiam como um clarão na sombra. (RAMOS, 2007, p. 7-8).

Nesse início, o diarista recupera a experiência de viagem, um mês depois do seu retorno ao Brasil, e discorre sobre os empecilhos que dificultavam a execução da "aventura singular": sua condição financeira, o medo de avião, as marcas indeléveis da perseguição política na memória do ex-prisioneiro (RAMOS, 2007, p. 7-8). Ironicamente, no entanto, ele parece atender a desígnios maiores quando se vê metido, "um dia, na encrenca voadora", planando sobre a África, a Europa, o Mediterrâneo, a planície do Cáucaso - uma referência ao cruzamento de fronteiras em direção ao mundo da "utopia realizada", momento que Sylvia Saítta define, nos relatos de viagem à URSS escritos por militantes no século XX, como o capítulo fundacional desses textos (SAÍTTA, 20I3, p. 6I-70).

7 O trabalho de Raquel Mundim Tôrres recupera e analisa detidamente os primeiros relatos de militantes brasileiros enviados à URSS entre o final dos anos I920 e o início dos I930 (Maurício de Medeiros, Osório César, Cláudio Edmundo, Juvenal Guanabarino e Caio Prado Júnior), sob o impacto do I Plano Quinquenal. A autora conclui que tais relatos constituem uma espécie de "reflexo" para que esses viajantes pensem suas próprias sociedades de origem, o que não exclui, todavia, a percepção de determinados problemas, como a "falta de alimentos, o problema da habitação e a censura" (TÔRRES, 20I3, p. I64). 


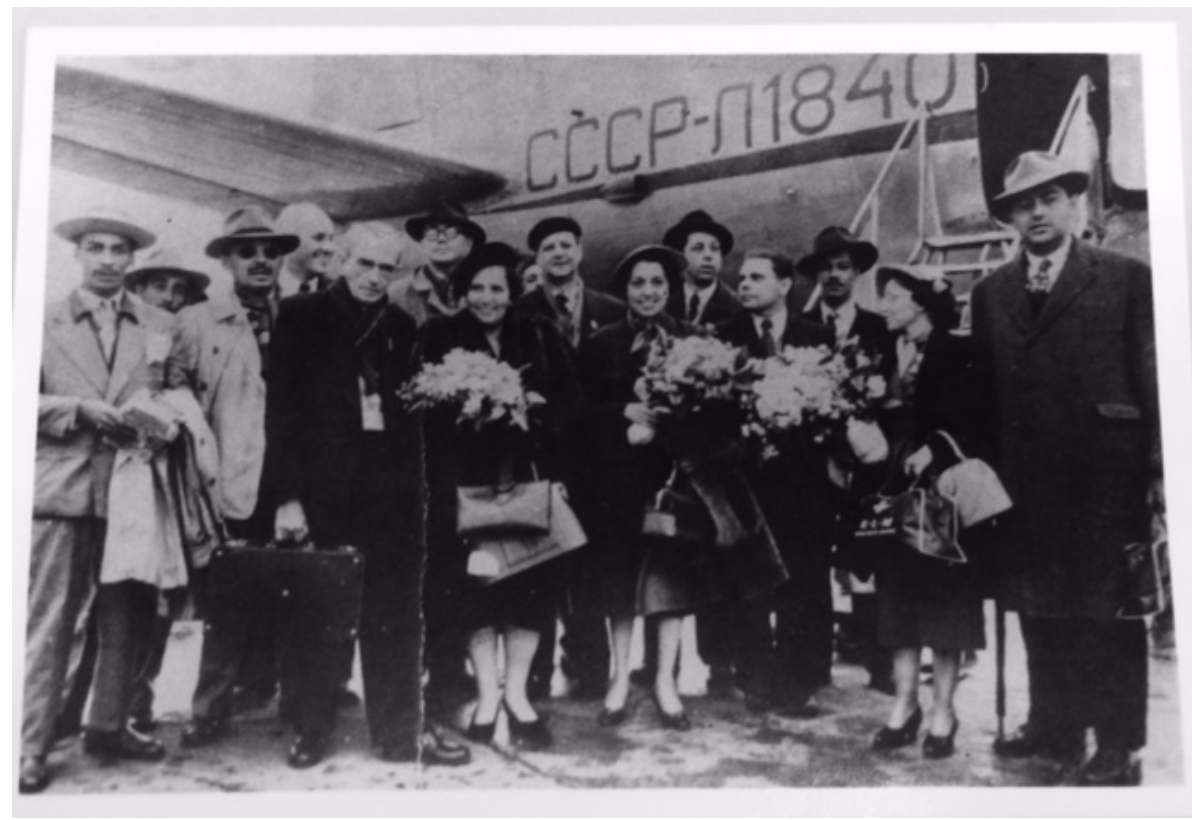

Figura 2 - Graciliano e Heloísa Ramos desembarcam em Moscou no dia 28/4/1952, juntamente com a comitiva do Partido, para as comemorações do 1ํ de Maio. Fundo Graciliano Ramos, IEB/USP. Referência: GR-F14-005

Transpondo os obstáculos imediatos à execução da empreitada, outro, mais complexo, surgia: sua ignorância com relação ao idioma russo e o necessário auxílio de vários intérpretes, que poderiam, segundo ele, turvar o que era dito aos viajantes: "na passagem de uma língua para outra o pensamento se modificava" (RAMOS, 2007, p. 8). Se há ciência do escritor quanto às perdas semânticas inerentes ao processo de tradução, parece haver também desconfiança quanto ao que era transmitido pelos intérpretes oficiais - peças-chave da propaganda stalinista, que selecionavam e adulteravam as informações em prol e a mando do governo soviético ${ }^{8}$. O desdobramento do excerto ratifica tal percepção:

O discurso pausado e conveniente, a amabilidade hospitaleira dos banquetes, a informação precisa e a estatística podem passar por nós sem deixar mossa. Não conseguiremos, porém, esquecer o transeunte disposto a ser-nos útil de qualquer modo, a criança gulosa de beijos num jardim de infância, o camponês curioso do Brasil, a polícia que, em vez de nos levar para a cadeia, como é natural, tenta auxiliar-nos se cometemos uma infração inadvertidamente. (RAMOS, 2007, p. 8-9.)

De forma indireta, o narrador trata, logo na abertura, das "técnicas de

8 Os intérpretes deveriam verificar os modos dos visitantes e explicar as perguntas mais "espinhosas" do modo mais compreensível. Como poucos visitantes eram fluentes no idioma russo, os guias e intérpretes eram "criativos, parciais ou mesmo mentirosos em suas traduções" (DAVID-FOX, 20I2, p. 54 -tradução nossa). 
hospitalidade", termo empregado por Paul Hollander para designar o conjunto de medidas estatais que visavam a influenciar a percepção e o julgamento dos convidados, induzindo-os a uma positiva e equivocada generalização diante do pouco que lhes era mostrado9. Em lugar de levar em conta as formalidades e os cenários minuciosamente preparados para a recepção das comitivas estrangeiras na URSS, que incluíam encontros importantes com diretores locais, discursos elogiosos e a seleção prévia do que poderia ou não ser exibido (uma reabilitação das cenográficas "aldeias-Potemkin" dos tempos de Catarina II) ${ }^{\text {ro }}$, Graciliano busca uma verdade oculta e mais espontânea sobre a vida soviética que, por meio de uma reflexão elaborada $a$ posteriori, permite a ele se desvencilhar, ao menos parcialmente, da representação construída pelos órgãos oficiais. A tentativa de contato com figuras anônimas, se parece livrar o diarista do direcionamento do olhar, não lhe permite, porém, uma segura avaliação do que viu:

Infelizmente não sei conversar, e na verdade observei pouco, em tempo escasso. Guardo impressões, algumas nítidas, que pretendo juntar, fazendo o possível para não cair em exageros. [...] Sinto-me no dever de narrar a possíveis leitores o que vi além dessas portas, sem pretender de nenhum modo cantar loas ao governo soviético. Pretendo ser objetivo, não derramar-me em elogios, não insinuar que, em trinta e cinco anos, a revolução de outubro haja criado um paraíso, com as melhores navalhas de barba, as melhores fechaduras e o melhor mata-borrão. (RAMOS, 2007, p. 9).

A recusa à visada apologética vem acompanhada da impossibilidade de elaborar uma impressão mais nítida dos países visitados: "da alma russa eu percebia retalhos", dirá o narrador ao final do livro (RAMOS, 2007, p. I43). Esse cuidado em não tomar como regra aquilo que foi visto, assumindo a limitação de um ponto de vista particular, contraria não apenas as expectativas do PCB pelo relato exultante e generalista, mas também o efeito almejado pela política de recepção de estrangeiros, em um momento histórico em que o regime soviético exercia o máximo de fascínio sobre o imaginário político dos militantes de todo o mundo. A postura cautelosa do diarista, explicitada na abertura do livro, tem implicações para o próprio andamento narrativo, como se verá.

9 A questão central seria saber o quão típico ou característico do todo seria a impressão incutida no visitante, que era inclusive afastado das áreas mais problemáticas (HOLLANDER, I983, p. I8-I9).

Io A aproximação dos lugares de peregrinação dos estrangeiros durante o stalinismo com as falsas fachadas de casas e aldeias construídas pelo marechal Potemkin, em I787, a fim de impressionar embaixadores europeus e convencê-los da felicidade dos camponeses sob o reinado de Catarina II, justifica-se porque, em ambos os períodos, um complexo foi erigido para enganar os visitantes (DAVID-FOX, 20I2, p. IOI). O roteiro bem como a escolha dos intérpretes e guias eram vistos pelo Estado soviético como uma importante decisão política, previamente aprovada pela alta hierarquia do Partido (DAVID-FOX, 20I2, p. I07). 


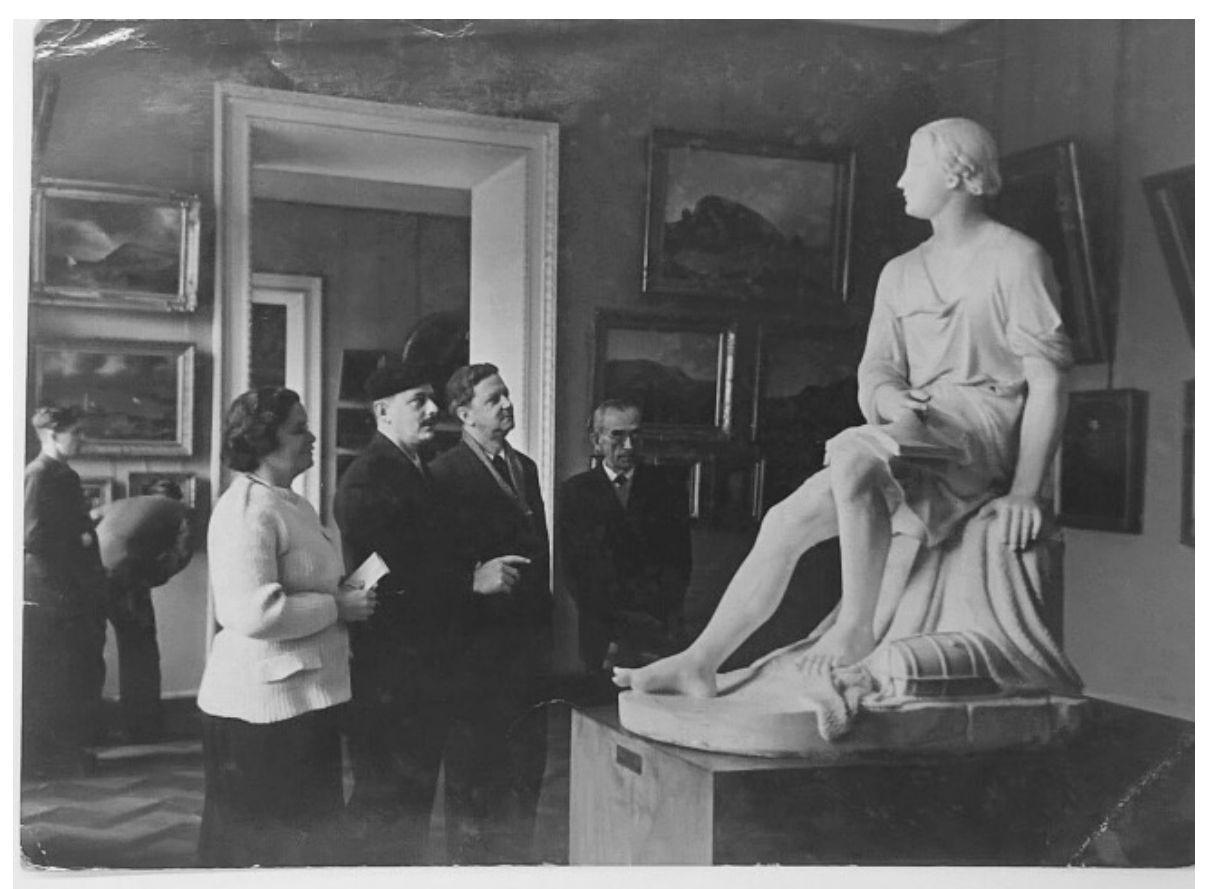

Figura 3 - Graciliano no Museu Russo de Leningrado diante da escultura Lomonósov adolescente em sua pátria, de A. Ivanov. Fundo Graciliano Ramos, IEB/USP. Referência: GR-F14-002

Estruturalmente, nos capítulos de Viagem que se seguem à abertura (escritos ainda durante o retorno de Graciliano ao Brasil, como indicam as datas e a referência aos locais em cada um deles), predomina a informação. É assim que o viajante relata sua passagem por Praga, onde encontra, hospedado no mesmo hotel, o amigo Jorge Amado; a recepção em Moscou, marcada pela presença de "fotógrafos e ramalhetes”; a caminhada pela Praça Vermelha e pelo Kremlin, quando vê a figura de Stalin por meio de um binóculo, e é repreendido por seguranças. No entanto, esse padrão narrativo, a partir do décimo capítulo - o primeiro escrito quando Graciliano já está no Rio de Janeiro -, parece ganhar uma tonalidade mais subjetiva e memorialística, ensejando uma representação da realidade soviética e do próprio viajante que, se não dispensa a informação, combina mais enfaticamente os dados empíricos com a interpretação sensível. Um desses momentos emblemáticos ocorre quando o visitante tenta conversar com um oficial condecorado, em uma casa de óptica:

Na sala, esperando a minha vez de ser atendido, percebi entre os numerosos fregueses um sujeito de farda e condecorações. Leviano, dirigi-me a ele, falei na guerra, mas a tentativa de relacionar-me com a força vista de longe, a $\mathrm{I}^{0}$ de maio, teve péssimo efeito. $\mathrm{O}$ homem sobressaltou-se, fixou-me um olhar feroz, rugiu uma sílaba e deu-me as costas. Esse procedimento não me ofendeu. Reconhecia-me indiscreto - e usara a indiscrição por dever de ofício. O meu desejo era omitir os discursos, as frases convenientes, as cortesias empregadas com exuberância pelos nossos hospedeiros. Envolviam-nos, desde a chegada, afirmações de paz, e algumas pessoas vacilavam, perguntavam se elas eram 
realmente sinceras. Podiam ser doses de morfina aplicáveis ao estrangeiro. Ficaríamos entorpecidos, regressaríamos docemente embalados, e ao cabo de alguns meses os telegramas nos anunciariam a catástrofe. [...] Não me importunavam tais reflexões. Achava-me efetivamente certo de que a guerra abreviaria a ruína do proprietário. Mas, de qualquer jeito, ele estava perdido; hoje ou amanhã se enterraria - e era doidice obter por elevado preço uma vitória infalível. Os patrões viveriam mais alguns anos, e entrariam suavemente na cova. Para que violências? Este juízo levava-me a aceitar sem dificuldade as opiniões vigentes na superfície onde me colocavam. Mas o desejo me vinha de entender-me com figuras anônimas, tentar adivinhar-lhes o pensamento. Diligenciaria fazer-me compreender utilizando fragmentos de línguas estrangeiras-e um olhar, um gesto, me revelariam de chofre coisas íntimas. (RAMOS, 2007, p. 60-6I).

O relato desliza das informações propriamente ditas para as reflexões do narradorviajante diante da tentativa de conversa e da cólera inesperada do oficial. É quando o ponto de vista narrativo se torna capaz de abarcar, momentaneamente, as dúvidas e vacilações dos que suspeitavam das afirmações de paz, como se vê na sequência da cena:

Que haveria nos miolos dos rijos militares vistos, a Iํ de maio, na praça Vermelha? A experiência me causou surpresa. [...] E a pergunta ocasionava indignação e raiva. Esquisito. Não me referira a uma luta possível, mas ao conflito passado, manifesto nas condecorações expostas na farda vistosa do oficial. Resignava-me a ser mal recebido. Assustava-me, porém, aquela fúria rápida como um relâmpago. Necessário refletir, arrumar discrepâncias. (RAMOS, 2007, p. 62).

Embora não haja uma conclusão explícita, são as ponderações do narrador que explicam o mal-entendido e o conduzem, indiretamente, a uma resposta: o oficial se melindrara porque o viajante teria aludido a uma nova guerra, e não ao conflito mundial do qual a URSS saíra vitoriosa. Como essa explicação é hipoteticamente atribuída ao militar pelo próprio narrador, que imagina o porquê de o oficial ter se zangado, o ponto de vista acaba por incorporar, incidentalmente, os questionamentos sobre o movimento pela paz mundial do qual muitos duvidavam ${ }^{\text {II }}$. Trata-se da campanha, lançada pela URSS em I949, de fortalecimento dos países do bloco soviético contra o "fascismo norte-americano", em um momento em que a corrida armamentista e as demonstrações de força nos países periféricos eram os elementos reguladores ${ }^{\mathrm{I} 2}$. Assim, o relato, nas passagens em que o foco se desloca para as reações do viajante, expõe um posicionamento nem sempre convergente com as posturas

II Os efetivos das Forças Armadas soviéticas aumentaram de 2,874 milhões para 5,763 milhões entre I948 e I955, sob o "pesadelo da agressão iminente" (RODRIGUES, 2006, p. II8). A campanha pela paz constituía, assim, um pretexto para subordinar o movimento comunista aos interesses da URSS e de sua política externa. I2 A respeito da intelectualidade brasileira no pós-guerra e o seu engajamento na campanha pela paz, ver: Arbex, 2012. 
públicas e conscientes do escritor no âmbito da militância, um traço disjuntivo presente em outros momentos do livro ${ }^{\mathrm{I} 3}$.

Ao mesmo tempo, ao se imaginar no lugar do oficial, é como se o narrador precisasse, ele mesmo, dar conta das respostas que não eram obtidas, uma vez que as conversas espontâneas transformavam-se em solilóquios diante de um Estado policial enraizado em toda a sociedade: na URSS do pós-guerra, o mais breve contato com um estrangeiro poderia levar à detenção por espionagem (FIGES, 20Io, p. 597). O diálogo truncado com o oficial, então, parece mimetizar a atmosfera repressiva que pairava sobre a sociedade da época, e, de modo mais vertical, aponta para questões próprias da oficialidade, uma vez que Stalin promoveu gigantesca depuração no Exército a partir de I945 ao prender e executar comandantes veteranos acusados arbitrariamente de traição (FIGES, 20Io, p. 533); mantendo a URSS cada vez mais isolada, o dirigente proibiu ainda os soldados soviéticos egressos da Alemanha, ou de qualquer outro país, de contarem as suas experiências do front (DEUTSCHER, I967, p. 549). É essa realidade de censura e repressão como forma de garantir a realização de um controvertido plano econômico ${ }^{\mathrm{I} 4}$ que Graciliano tenta, dentro de suas possibilidades, entender.

Em meio a um campo minado, a apreensão subjetiva daquela realidade nova e o travamento básico que decorre dessa apreensão parecem ser o forte do livro, pois formam um contraponto, por assim dizer, com os momentos de maior adesão ideológica, nos quais predominam a descrição da paisagem e a transcrição de dados. Como a visita, na Geórgia, ao kolkhoze Kheivani, parte do cultural show previamente traçado para estrangeiros, fazenda coletiva que o viajante descreve como uma "terra fértil com mulheres férteis” ${ }^{5}$. Ou mesmo a aparição de Stalin no Kremlin, a quem o diarista chama de "tremendo condutor de povos", embora a imagem do homem

I3 Sobre a participação do escritor na "campanha pela paz", Thiago Mio Salla registra que "Graciliano foi legalmente dono e editor responsável do jornal Partidários da paz”, jurado dos Prêmios da Paz, fundador e conselheiro do Movimento Brasileiro dos Partidários da Paz, diretor da Organização Nacional de Defesa da Paz e Cultura, participante do Congresso dos Partidários da Paz, em São Paulo, e delegado eleito para o $2^{\circ}$ Congresso Mundial dos Partidários da Paz (SALLA, 20Io, p. I23).

I4 A volta da "economia mobilizada", que priorizava a indústria de base em um momento de carência de bens de consumo provocada pela Segunda Guerra Mundial, implicou também o controle estatal sobre os camponeses, e, como forma de se manter à força a coesão social, a ampliação do regime de terror policial e de repressão severa, ultrapassando inclusive a cifra dos expurgos de I937-38 e chegando, conforme Aarão Reis, a um novo auge em I949-50, “com mais de 2,4 milhões de presos registrados" (REIS, 2002, p. I79).

I5 Talvez essa seja a explicação para o fato de “O Kolkhoze Kheivani” ter sido o único capítulo do livro publicado no periódico comunista Imprensa Popular, em julho de I952, quando o escritor ainda era vivo. O jornal carioca Correio da Manhã, de 6 de novembro de I954, registrava que Viagem fora "interditado no departamento de publicidade do órgão oficial do PC, que se recusou a aceitar qualquer anúncio da obra” (Fundo Graciliano Ramos, IEB/USP). Também Rubem Braga denunciava que "o jornal comunista aplicou a pena do silêncio ao livro de Graciliano Ramos” (BRAGA, I954). Assim como aconteceu com as Memórias do cárcere, o PCB optava pelo silêncio público. 
"gordo e curvo", entrevisto por um binóculo, destoe fortemente das representações agigantadas do líder ${ }^{16}$.

O caráter ambivalente e construído da obra foi desconsiderado por parte da fortuna crítica, que preferiu condenar a narrativa de viagem ou confiná-la à mera informação. Para Maurício de Medeiros (I954), o livro era um registro "enfadonho", prova da "ingenuidade pasmosa do autor". Jorge Abrantes (I954) afirmava que Graciliano pintara a URSS como um "verdadeiro paraíso". Em matéria recente, Daniel Lopes (20II) volta a ressaltar a "cegueira" do escritor ante o que viu, sendo o diário uma amostra do "estrago que as ideologias podem fazer mesmo nas mentes mais brilhantes". No entanto, outros críticos atentaram para as nuances da narrativa desde o seu lançamento. Serra Barros (I955) afirmava que Viagem era a "vitória da ironia sobre a ingenuidade, claramente vislumbrada a cada linha envernizada do pequeno diário". Valdemar Cavalcanti declarava que a passagem de Graciliano pelo mundo soviético se fazia com os olhos voltados "menos para as realidades ambientes do que para o próprio escritor em trânsito", e que importavam mais o viajante e suas reações do que a própria viagem. "Pouco a pouco", dizia o crítico, "se vai acinzentando o meio físico e social que ele pretendia pintar com o colorido autêntico, para destacar-se logo a personalidade do autor" (CAVALCANTI, I954). E Olívio Montenegro, também em I955, via no diário "um tom sibilante de polêmica", posto que o melhor do livro era mesmo "o que vinha das impressões mais livres e mais espontâneas” do viajante (MONTENEGRO, I955). A recepção da obra, aqui sumariamente sintetizada, permite então repensar aquilo que foi entendido como uma adesão sem reservas, por parte de Graciliano, ao stalinismo: até que ponto, de fato, os apontamentos do diarista e a forma criada pelo escritor corroboram a "visão do paraíso" entrevista por alguns críticos?

I6 "Significativamente, todos os filmes e fotografias ocultavam o fato de que ele [Stalin] tinha apenas I,58 metro” (HOBSBAWM, I995, p. 379). 


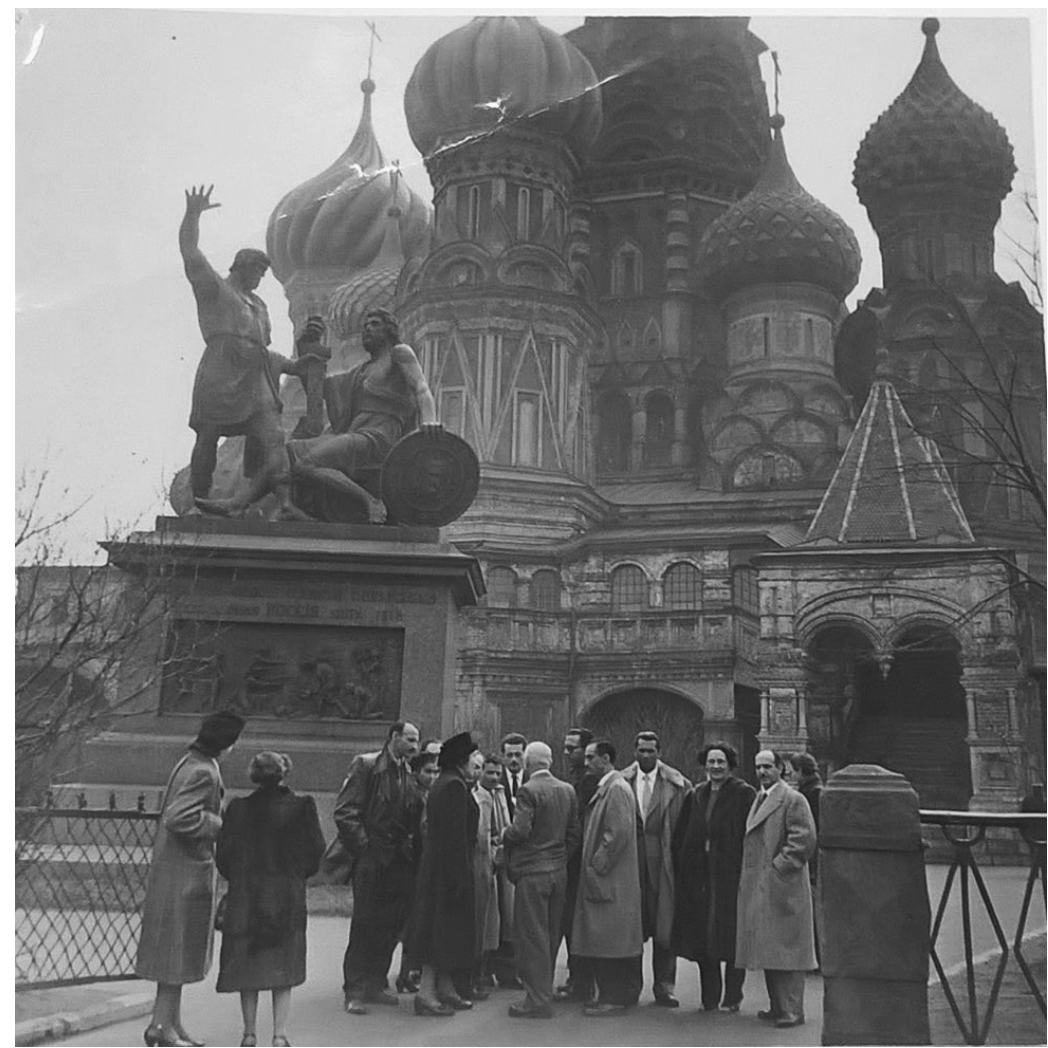

Figura 4 - A comitiva brasileira e a Catedral de São Basílio, na Praça Vermelha. Fundo Graciliano Ramos, IEB/USP. Referência: GR-F14-014

A resposta a esse questionamento passa necessariamente pela dimensão reflexiva do livro, traço pouco comum a um relato de militante em tempos de aguda ortodoxia, que dá ensejo a um olhar mais apurado e a hesitações bastante reveladoras. Tal dimensão aparece claramente quando o narrador discorre sobre sua passagem por Praga, onde trava um primeiro contato com a Sociedade para as Relações Culturais da URSS com os Países Estrangeiros, a VOKS:

Pela manhã, depois do café, um rapaz amável veio convidar-me para um passeio nos arredores. Tencionava mostrar castelos, várias preciosidades tchecas que certamente não me seria possível rever. Entrei no automóvel, ignorando quem fazia o convite. Ainda hoje ignoro. Possivelmente foi a VOKS, entidade forte, polimorfa, visível ao mesmo tempo em diversos lugares. (RAMOS, 2007, p. I9).

O excerto revela duas temporalidades: a do viajante, que recebe o convite para conhecer a cidade; e a do narrador-diarista, que atribui à poderosa VOKS, no momento em que escreve o relato, a designação do roteiro percorrido. Criada em I925, a VOKS, desde muito cedo sob controle do Partido, tinha como tarefa formar uma opinião pública favorável à União Soviética no exterior; cabiam-lhe 
inicialmente o exercício de uma diplomacia cultural, por meio do convite de delegações estrangeiras, e o estabelecimento de roteiros previamente determinados que fornecessem imagens positivas dos lugares visitados. Aos poucos, a entidade foi se tornando um ator auxiliar da polícia secreta soviética: nos anos I950, diante do isolacionismo, da xenofobia e do triunfalismo oficial, ao invés de encorajar, a finalidade da VOKS era mesmo a de restringir o intercâmbio de conhecimentos e a promoção da cooperação real (DAVID-FOX, 20I2, p. 3I9). Existem muitas passagens do livro que revelam o incômodo de Graciliano com o controle permanente que o cercou enquanto visitante. Quando, ainda em Praga, a delegação se dirige à VOKS para agradecer pela hospedagem, o diarista registra:

Desde a chegada a Praga, achava-me entregue à poderosa instituição, vivia à custa dela, e era doloroso achar-me a causar dano a estrangeiros solícitos. Não me consentiam pagar um cálice de vodka, um maço de cigarros. A fumar e a beber, julgava-me parasita: na lavoura e na fábrica pessoas mourejavam para sustentar-me o ócio inútil. Diante da mesa larga coberta de frutos e garrafas, os meus escrúpulos se desvaneceram. Abafaram-nos logo os agradecimentos convencionais, e um professor, loquaz, pequeno, de idade ambígua, a cabeça pelada, incutiu-me, em longo discurso, a impressão de que realizávamos todos uma tarefa. Era sem dúvida um disparate, mas os russos têm a habilidade espantosa de, obsequiando-nos, sugerir que lhes fazemos obséquio. (RAMOS, 2007, p. 36-37).

Embora não haja uma crítica explícita, o narrador deixa patente o seu desconforto com a prodigalidade da recepção ao relacioná-la com as massas de trabalhadores que garantiriam o funcionamento da burocracia de Estado. Especialmente porque o aparato burocrático, caminhando pari passu com a industrialização orientada, desenvolveu-se às custas do sacrifício de camponeses e operários (REIS, I983, p. 40).

Há também, no fragmento transcrito, a percepção do narrador de que um senso de missão estava sendo incutido nos visitantes, e a menção à "habilidade espantosa" dos russos alude à manipulação e à inversão de papéis que ele tenta entender. $\mathrm{O}$ "professor loquaz" é o mesmo que, diante das dúvidas sobre o roteiro, afirma aos viajantes que iria "proceder ditatorialmente, forçando-os a visitas de que não se lembravam” (RAMOS, 2007, p. 37). Mais uma vez, entra em cena a atuação da VOKS, e se ainda em Praga soa como disparate a insinuação da tarefa que lhes era delegada, dúvidas não restarão quando o presidente da União dos Escritores Georgianos, já ao fim da excursão, afirma ao escritor que "a viagem renderia um livro" (RAMOS, 2007, p. I83). Como se vê, no caso específico dos mecanismos de cooptação, Graciliano, ao mesmo tempo que realiza a tarefa partidária de escrever o diário, parece se dar conta daquilo que efetivamente estava em jogo.

$\mathrm{Na}$ obra, o contraponto ao controle estatal vai se adensando, como quando o viajante se perde pelas ruas de Moscou e tenta voltar ao hotel depois de visitar o Kremlin:

Não me seria difícil orientar-me, e agradava-me ficar livre de guias e intérpretes, caminhar nas ruas só, errando, acertando, fora do carreiro de formigas, habitual desde a nossa chegada. Barbantes invisíveis nos amarravam pernas e braços, 
e as amabilidades excessivas começavam a pesar-me; aceitá-las parecia-me às vezes obrigação penosa. O afastamento de cerimônias e cortesias surge-nos como libertação. (RAMOS, 2007, p. 76).

A ciência quanto à vigilância ininterrupta aparece expressa pela imagem literária dos "barbantes invisíveis" que o narrador constrói. A boa vontade inicial dá lugar ao fastio e à certeza de que seria preciso escapar do roteiro e das cortesias previamente estabelecidas. De modo que o tom mais crítico, de alguém que vê e que se sabe monitorado, insinua-se no diário progressivamente. Ao discorrer sobre a visita a uma escola-modelo na Geórgia, o diarista reitera o seu alívio por não contar com a presença da diretora, que, se estivesse presente, "fecharia portas", "cochicharia a funcionários" e "puxaria cordões de títeres” (RAMOS, 2007, p. I08). Na passagem por uma fábrica de meias, ele nota que várias inspetoras os seguiam, "deslizando como sombras" (RAMOS, 2007, p. II7). Dentro do Instituto Marx-Engels, intriga-se com uma "rapariga" que lhe toma das mãos, de forma impetuosa, o seu caderno de notas. "Por que [...] invadir-nos as almas, oferecer uma camaradagem possivelmente indiscreta?”, pergunta ironicamente (RAMOS, 2007, p. I68). Se cabia à VOKS impedir a percepção da vigilância a que os viajantes eram submetidos, a transcrição literária da viagem de Graciliano parece revelar que, mesmo no interior da militância pecebista, houve muito mais do que adesões cegas diante do que foi mostrado ${ }^{\text {T7}}$. De modo geral, a representação dos viajantes como marionetes e a certeza de ser vigiado, expressa em Viagem por um vocabulário ligado ao controle e à devassa, dão a medida do apego de Graciliano à experiência, a qual sempre foi para ele, segundo Antonio Candido, um "atrativo irresistível" (CANDIDO, 2006, p. 82). Esse apego ao que foi tocado pela sensibilidade impede o diarista de ceder a uma reprodução ideológica da vida soviética, desviando-se, até certo ponto, do imaginário previamente construído dentro dos quadros da militância.

Corrobora para o olhar ambivalente a dramatização da experiência de viagem, transcrita em forma de diário, mas que não se afina com as definições correntes do gênero ${ }^{\mathrm{I} 8}$. Trata-se, nesse caso, de um registro que, se por um lado assinala a entrada dos dias, o que confere ao relato um caráter mais imediato, por outro se revela como uma narrativa construída depois da expedição à URSS, quando Graciliano já se encontrava na França a caminho do Brasil. As anotações a seco inerentes ao gênero, então, parecem se alargar por meio de uma elaboração mais refletida, a qual garante a pertinência sistêmica das ponderações do narrador-viajante e a formalização de uma realidade histórica específica. Como consequência, as entradas independentes do diário não elidem o recorte raciocinante da prosa, a articulação implícita dos seus segmentos e a força poética expressa em alguns dos capítulos significativos.

I7 Segundo Michael David-Fox (20I2, p. 3 - tradução nossa), a reação dos visitantes "é frequentemente um amálgama complexo que inclui reações mais críticas e negativas do que o que havia sido suposto" diante de uma viagem que constitui um raro momento de contato entre o Ocidente e o Oriente.

I8 "Uma obra aberta, que não procura se perpetuar; uma sequência de instantes que não visam a uma totalidade; uma escrita hesitante e tateante, marcada pelo momento": essas são as características tradicionalmente atribuídas ao diário, elencadas por Georges Gusdorf (I99I, p. 3I7-346 - tradução nossa). 
É pela articulação implícita com os "barbantes invisíveis" mencionados nos capítulos sobre a Geórgia que se pode ler, também criticamente, a narração da visita de Graciliano ao Teatro Bolshoi, em Moscou. Admirado com a presença de trabalhadores na plateia, o viajante não deixa de se espantar com o espetáculo apresentado:

Começou a representação de Romeu e Julieta, num bailado sábio, alto em demasia para as minhas limitações. Não me seria possível dizer por que aquilo era grande, por que o público julgava Ulanova a maior dançarina do mundo. Surpreendia-me a reconstituição rigorosa da época soturna em que a tragédia se desenvolveu, e mais me espantava haverem transformado um caso de amor, uma luta de famílias, em vasto movimento de massas. No admirável conjunto às vezes sobressaíam figurinhas exíguas. Na peça corriam as festas, a procissão, os duelos - e dois pequenos vagabundos, a um canto, dançavam agitando seus farrapos de seda, brigavam, reconciliavam-se, metiam as mãos nas algibeiras do frequentador da taberna, pediam esmolas, furtavam a bolsa da velha devota a caminho da missa. [...] Uma ideia me atenazava: Shakespeare ressurgia, levava ao delírio os trabalhadores de um país bárbaro no tempo dele. (RAMOS, 2007, p. 43-44).

Além de reconhecer a sua incapacidade para julgar a performance de Galina Ulanova (a bailarina mais premiada da história da URSS), o estranhamento diante do número é patente: a tragédia de Shakespeare havia se tornado, nas mãos do compositor Serguei Prokofiev, "um vasto movimento de massas" balé roça o irônico, pois mostra como o "admirável conjunto" épico se sobrepunha à história dos "dois pequenos vagabundos" (as personagens principais do enredo) que dançavam, entretanto, escanteados. Como o próprio segmento indica, o espanto do narrador guarda relações com a transformação radical por que passou o texto shakespeariano, de tragédia lírica a um épico redentor e coletivista. Se há certo fascínio pelo acesso real dos trabalhadores russos aos bens de cultura ("a arte agora tem finalidade bem diferente da que lhe conferiam"), não menos significativa é a percepção de que o núcleo romântico das cenas não se ajustava, na montagem, ao reenquadramento épico - um problema estrutural, por assim dizer. Embora sutil, o questionamento alcança um dos pilares do stalinismo desde os anos I930: o realismo socialista, corrente artística que referendava a linha ideológica do Partido e que se caracterizava pela valorização de um "herói positivo" como o representante virtuoso das massas ${ }^{20}$. Tratava-se de pesada camisa de força que, sob a tutela do secretário

I9 Marco Aurélio Bueno trata da controvertida relação do compositor ucraniano com o poder stalinista: "não havia dúvida de que uma vez mais as autoridades soviéticas haviam conseguido seduzir Prokofiev: teatros lotados, público caloroso e resenhas favoráveis ressaltavam o fato de 'Prokofiev ser um dos mais importantes compositores russos'. Foi-lhe posto à disposição um belo apartamento em Moscou, carro com motorista e solicitadas duas novas obras: a trilha sonora para o filme satírico $O$ tenente Kijé e a partitura para o balé Romeu e Julieta, que embora escritas em Paris eram destinadas ao público soviético e, portanto, adotam uma linguagem bastante direta e acessível, de lirismo intenso e melodias eloquentes, bem de acordo com a estética do realismo socialista defendida pelo regime" (BUENO, 20Io, p. 222).

20 Sobre a estética do realismo socialista ("sotsrealizm"), em vigor desde o I Plano Quinquenal, mas retomada intensamente no pós-guerra, ver: Andrade, 20I0, p. I6I-I63. 
Andrej Jdanov, recaía sobre artistas e escritores alinhados ao Partido em todo o mundo, diretriz que Graciliano fez questão de rechaçar ${ }^{21}$.

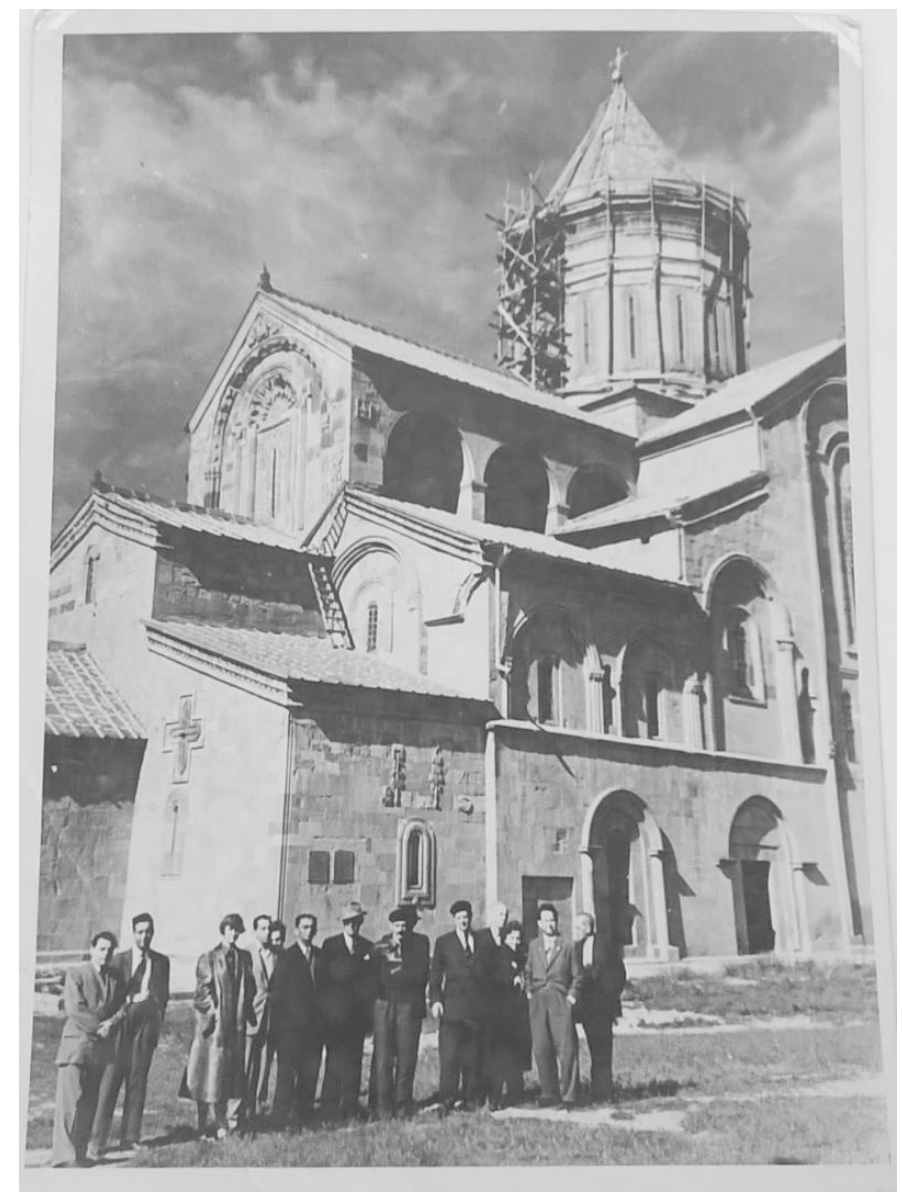

Figura 5 - Graciliano (o último à direita), Dalcídio Jurandir (o quinto) e amigos em frente à catedral Svetitskhoveli, na Geórgia. Fundo Graciliano Ramos, IEB/USP. Referência: GR-F14-013

Como se pode notar, os momentos que se aproximam da interpretação sensível garantem a força do conjunto pelo poder de revelação contraideológica que contêm. Amarga e de feitio propriamente literário, a visita ao sanatório georgiano, já ao final

2I Em “O Partido Comunista e a criação literária” Graciliano declara: "E é claro que não haveria conveniência em fabricar normas estéticas, conceber receitas para a obra de arte. Cada qual tem sua técnica, o seu jeito de matar pulgas, como se diz em linguagem vulgar" (RAMOS, 20I2, p. 260). Sobre o mesmo tema, Dênis de Moraes transcreve uma conversa de Graciliano com o jornalista Heráclio Fortes: “- Nenhum livro do realismo socialista lhe agradou? - Até o último que li, nenhum. Eu acho aquele negócio de tal ordem ruim que não aceitei ler mais nada. [...] A literatura é revolucionária em essência, e não pelo estilo do panfleto" (MORAES, 20I2, p. 253-254). 
do volume, talvez seja a cena mais eloquente do diário, uma vez que parece sintetizar a experiência do escritor nas terras soviéticas:

Árvores domesticadas a tesoura socializavam-se no jardim do sanatório. Descemos a escadaria larga, de pedra; recebeu-nos uma profusão amável de flores desconhecidas, manchas vivas e alegres no ar luminoso [...]. Incapaz de achar sentido no mármore, acolhi-me à sombra de plantas que me poderiam dizer qualquer coisa. Vegetais amigos. De repente uma surpresa me embasbacou: entre caules estranhos, folhas esquisitas, surgiu-me um pé de quipá. Abri os olhos, capacitei-me de não me haver enganado. Num instante esqueci as palmas que se agitavam mansas na aragem, os troncos armados de puas inócuas: esses viventes eram talvez originários dali, parentes de outros do meu país. O pé de quipá, brasileiro como eu, nascera no sertão, viera acomodar-se no ambiente impróprio. E isolava-se, nenhum companheiro. Juntei recordações da infância: o Nordeste queimando ressurgiu, a campina deserta onde avultavam, de espaço a espaço, nódoas verdes como aquela, próxima de meus dedos. Examinei o patrício desterrado, sem receio de ferir-me nos espinhos, e caímos num diálogo silencioso. Um cardo como os outros da minha terra, inteiramente igual; nada sofrera na adaptação. Metro e meio de altura, mais ou menos. Bem grande, sim senhor; tamanho razoável. Não se distinguia dos que utilizei com abundância em vários livros e tornaram as minhas páginas secas, ásperas, espinhosas. Como diabo tinha vindo ali ganhar raízes aquele pé de quipá? O conterrâneo fragoso não me deu resposta. (RAMOS, 2007, p. I45-I46).

O excerto surpreende pela alta voltagem lírica e poder de síntese. $\mathrm{O}$ encontro insuspeitado do viajante com o cacto, quase uma miragem, remete-lhe instantaneamente à sua terra de origem. Como, afinal, o cardo fora parar em terras soviéticas? "Isolado", "sem nenhum companheiro", o "patrício desterrado" permitiria ao estrangeiro entabular uma conversa espontânea, fora do cerco policial e das formalidades encomiásticas. O “diálogo silencioso" não lhe dá, no entanto, as respostas ansiadas. É como se o próprio cacto se recolhesse ao silêncio imposto, e nem mesmo a familiaridade entre ambos fosse capaz de despertá-lo do mutismo, estendido tacitamente ao viajante. Desse modo, a imagem do cacto solitário e mudo em meio à planície do leste parece ser o correlato objetivo da própria sensação de deslocamento do escritor, que atravessa todo o diário e funciona como uma espécie de contraponto aos momentos mais apologéticos do texto ${ }^{22}$. Como a confirmar o imaginário de exílio e de inadequação representado pelo cacto e o quanto a planta sintetiza a experiência do viajante, não parece casual que, diante das perguntas inconvenientes de Graciliano a respeito da literatura georgiana, o presidente da Associação dos Escritores explicite a uma das guias sua opinião sobre o escritor brasileiro. A intérprete, segundo o diarista, "valeu-se de um adjetivo francês que significava, aproximadamente, 'espinhoso'. Não era bem isso, mas ficou isso, em falta de coisa melhor" (RAMOS, 2007, p. I76). Note-se que é o diarista quem define o

22 Para Valentim Facioli (1987, p. 22I), além de denotar "forte poder de observação", Viagem é um texto "cujo equilíbrio precário merece análise”. 
termo a ele atribuído, o que dá a medida da sua autopercepção. Ou seja: os laivos de espontaneidade resultam em impertinências que ele e os anfitriões percebem; daí porque o olhar sobre a vida soviética não permitirá qualquer tipo de generalização, como ele conclui ainda no sanatório:

Não me era possível ir ao Volga. E se fosse possível, deter-me-ia ignorando sempre a alma russa: para entendê-la seria preciso que eu tivesse alma igual. E éramos diferentes. Reduziam-se as distâncias, mas as línguas nos afastavam. Sentia-me na dependência de Tchugunov, de Kaluguin, da sra. Nikolskaya, de Tchimakadze [os intérpretes que o acompanharam]. Muralhas nos separavam de gente próxima. Queriam dar-nos muito, e estávamos forçados a receber migalhas. (RAMOS, 2007, p. I42-I43).

O contraponto entre a expectativa dos anfitriões e a frustração do viajante não poderia ser mais explícito, e a menção às "muralhas" tanto pode se referir às óbvias diferenças culturais quanto às menos evidentes limitações impostas pelos guias. Mas, para além do seu sentido imediato, a imagem do cacto mudo e desterrado guarda relações, ainda, com a própria estrutura do livro. Como foi dito, há um vetor de apreensão subjetiva que liberta o diário de um registro puramente informativo, incluídas as conversas protocolares, pois o viajante, depois de descrever cada lugar visitado, sistematicamente se debruça sobre as suas próprias reações - um mecanismo compensatório diante dos parcos esclarecimentos e dos contatos espontâneos que ele não conseguiu travar. Corrobora esse efeito da forma uma constelação, no plano do enredo, de diálogos truncados, inconveniências e desencontros de toda ordem ${ }^{23}$. Assim é que os capítulos vão se abrindo às elucubrações do narrador, e o texto ganha uma tonalidade memorialística e autorreferente, quando então duas realidades se sobrepõem em cada uma das entradas: a das exterioridades convencionais e frias, e as impressões silenciosas elaboradas pelo sujeito, muitas vezes destoantes do protocolo e de suas próprias ações "externas". Esse constante deslocamento de foco do mundo observado para as reações subjetivas, que abre mão de qualquer tipo de comunicação imediata e põe em questão as próprias tentativas de contato, parece estilizar a experiência truncada de aproximação do intelectual militante com uma sociedade silenciada, que, sob Stálin, foi capaz de internalizar o Estado policial como parte de sua própria identidade, a ponto de milhões de pessoas comuns serem transformadas, voluntária e involuntariamente, em "espectadores silenciosos ou colaboradores de seu sistema de terror" (cf. FIGES, 20Io, p. 26-27). Cabe ressaltar que, de modo ainda mais catastrófico, depois do êxito na Segunda Guerra Mundial, o sistema social e político soviético adquiriu novos e sinistros aspectos de caráter burocrático e policial

23 Como a represália de um guarda pelo fato de o viajante usar um binóculo no Kremlin (cap. IX); a advertência de uma senhora anônima, por jogar cigarros no chão (cap. V); a conversa “charlatã”, repleta de perguntas inconvenientes, com o presidente da União dos Escritores Georgianos (cap. XXXI); a sua perplexidade, na fila para a visita ao túmulo de Lenin, diante do estranho cochicho do guia a um anônimo para que os visitantes fossem inseridos nela (cap. XII); a desconcertante tentativa de conversa com a moça que fora apresentada pelo intérprete como uma "princesa legítima”, mas que na verdade descendia da nobreza (cap. XXVI). 
(cf. VOLKOGONOV, 2004, p. 543)24. Em suma, a vigilância permanente e o bloqueio impostos aos visitantes são estilizados pelo movimento do livro, cujo ritmo capta o murmúrio dos que não podem falar abertamente, incluindo-se o próprio narrador. Trata-se, enfim, de uma forma literária que enfrenta de modo sibilino, nas palavras do diarista, o "cerco impertinente e amável que nos tolhia os passos desde a chegada" (RAMOS, 2007, p. I85) - paradoxo revelador, pois expõe o quanto o militante se sentia atraído pelas "cidades veneráveis" ao mesmo tempo que percebia as técnicas de hospitalidade como indesejáveis tentáculos do Estado autocrático.

Portanto, a obra derradeira de Graciliano, se traz passagens ideológicas e paga tributo às paixões da época, também é capaz de captar sensivelmente, por meio da respiração do texto, as forças mais profundas do mundo observado. Tal capacidade dá a ver o realismo avançado do escritor, tão decantado em seus outros livros, porém pouco considerado pela crítica no relato de viagem. Esse realismo se revela na apreensão de um ritmo social que, a um só tempo, diz respeito tanto à nova realidade observada como aos círculos políticos locais aos quais o militante pertencia ${ }^{25}$. O resultado é surpreendente, em especial se levarmos em conta o aspecto descarnado da prosa do diário, que potencializa o rendimento estético que o autor conseguiu extrair de sua própria trajetória. Um livro, enfim, reduzido ao elementar e à primeira vista conformado com as diretrizes partidárias, mas cujo sentido profundo guarda, como não poderia deixar de ser no caso de Graciliano, considerável poder de afronta.

\section{SOBRE O AUTOR}

FABIO CESAR ALVES é docente da área de Literatura Brasileira do Departamento de Letras Clássicas e Vernáculas da Faculdade de Filosofia, Letras e Ciências Humanas da Universidade de São Paulo (DLCV/FFLCH/USP).

E-mail: fabiocesaralves@usp.br

24 O biógrafo afirma que Stalin foi capaz de "combinar o incombinável, mantendo, por todos os meios possíveis, o entusiasmo e o zelo do povo soviético pela crença de que a terra da promissão estava logo ali, enquanto, ao mesmo tempo, ameaçava seus concidadãos com o terror individual e de massa” (VOLKOGONOV, 2004, p. 543).

25 A pesada ortodoxia partidária e a intolerância com opiniões divergentes radicalizaram-se ainda mais no período posterior à filiação de Graciliano ao PCB, quando o Partido é novamente posto na ilegalidade, adotando uma postura ultraesquerdista como resposta à repressão interna e à polarização internacional. A falta de comunicação entre as bases e a esclerosada cúpula "aumentou ainda mais o fosso entre o Partido e as massas" (CHILCOTE, I982, p. 30I). 


\section{REFERÊNCIAS}

ABRANTES, Jorge. Livros em conflito. Diário da noite. Recife, 30 dez. I954.

AMADO, Jorge. O mundo da paz: União Soviética e democracias populares. Editorial Vitória, I954.

ANDRADE, Homero Freitas de. O realismo socialista e suas (in)definições. Literatura e Sociedade, n. I3,

São Paulo, 2010.

ARBEX, Luciana Bueno Marta. Intelectualidade brasileira em tempos de Guerra Fria: agenda cultural, revistas e engajamento comunista. I32 f. Dissertação (Mestrado em História Social). Faculdade de Filosofia, Letras e Ciências Humanas, Universidade de São Paulo, São Paulo, 2012.

BRAGA, Rubem. Rússia. Folha da Tarde. Porto Alegre, I5 nov. I954. Fundo Graciliano Ramos, Série Fortuna Crítica, Subsérie Matérias Extraídas de Periódicos, IEB/USP.

BUENO, Marco Aurélio. Círculos de influência - a música na União soviética: da revolução bolchevique às gerações pós-Shostakóvich. São Paulo: Algol, 2010.

CANDIDO, Antonio. Fiç̧ão e confissão: ensaios sobre Graciliano Ramos. Rio de Janeiro: Ouro sobre Azul, 2006.

CAVALCANTI, Valdemar. Jornal literário. O Jornal. Rio de Janeiro, 25 nov. I954. Fundo Graciliano Ramos, Série Fortuna Crítica, Subsérie Matérias Extraídas de Periódicos, IEB/USP.

CHILCOTE, Ronald. O PCB: conflito e integração. Rio de Janeiro: Graal, I982.

DAVID-FOX, Michael. Showcasing the great experiment: cultural diplomacy and western visitors to the Soviet Union, I92I-I94I. New York: Oxford University Press, 2012.

DEUTSCHER, Isaac. Stalin: a história de uma tirania. Trad. José Laurênio de Melo. Rio de Janeiro: Civilização Brasileira, I967.

FACIOLI, Valentim. Graciliano Ramos: antologia e estudos. São Paulo: Ática, I987.

FIGES, Orlando. Sussurros: a vida privada na Rússia de Stalin. Trad. Marcelo Schild e Ricardo Quintana. Rio de Janeiro: Record, 2010.

FUNDO GRACILIANO RAMOS, Série Fortuna Crítica, Subsérie Matérias Extraídas de Periódicos, IEB/USP. GUSDORF, Georges. Le jornal: dire ma vérité. In: . Les écritures du moi. Lignes de vie I. Paris: Odile Jacob, I99I.

HOBSBAWM, Eric. Era dos extremos: o breve século XX, I9I4-I99I. Trad. Marcos Santarrita. São Paulo: Companhia das Letras, I995.

HOLLANDER, Paul. Political pilgrims: travels of western intellectuals to the Soviet Union, China, and Cuba. New York: Harper Colophon, I983.

LIMA, Felipe Victor. O Primeiro Congresso Brasileiro de Escritores: movimento intelectual contra o Estado Novo (I945). Dissertação (Mestrado em História Social). Faculdade de Filosofia, Letras e Ciências Humanas, Universidade de São Paulo, São Paulo, 2010.

LOPES, Daniel. Ensaio sobre a cegueira de Graciliano Ramos. Amálgama, 20 de janeiro de 20Ir. Disponível em: 〈https://www.revistaamalgama.com.br/oI/20II/cegueira-de-graciliano-ramos >. Acesso em: 27 jun. 2017.

MARQUES NETO, José Castilho. Solidão revolucionária: as origens do trotskismo no Brasil. Rio de Janeiro: Paz e Terra, I993.

MEDEIROS, Maurício de. Livro póstumo. A Gazeta, 24 nov. I954.

MONTENEGRO, Olívio. Viagem: Graciliano. O Jornal. Rio de Janeiro, 28 fev. I955. Fundo Graciliano Ramos, Série Fortuna Crítica, Subsérie Matérias Extraídas de Periódicos, IEB/USP.

MORAES, Dênis de. O Velho Graça: uma biografia de Graciliano Ramos. São Paulo: Boitempo, 2012. 
MORAES, Eneida. Caminhos da terra: URSS, Tchecoslováquia, China. Rio de Janeiro: Antunes Editorial, I959.

NEME, Mário, Plataforma da nova geração. Globo: Porto Alegre, I945.

PEREIRA, Astrojildo. URSS, Itália, Brasil. São Paulo: Novos Rumos, I985.

RAMOS, Graciliano. Viagem. Rio de Janeiro: Record, 2007.

. Garranchos. Textos inéditos de Graciliano Ramos. Organização Thiago Mio Salla. Rio de Janeiro: Record, 2012.

REIS, Daniel Aarão. Uma revolução perdida: a história do socialismo soviético. São Paulo: Fundação Perseu Abramo, 2002.

REIS, Daniel Aarão. O socialismo real. São Paulo: Brasiliense, I983.

RODRIGUES, Roberio Paulino. O colapso da URSS: um estudo das causas. Tese (Doutorado). São Paulo, FFLCH/USP, 2006.

SAÍTTA, Sylvia. Tren estación cielo. Estudios de Teoría Literaria, ano 2, n. 4, 2013.

SOTANA, Edvaldo. Relatos de viagens à URSS em tempos de Guerra Fria. Curitiba: Aos Quatro Ventos, 2006.

SALLA, Thiago Mio. O fio da navalha: Graciliano Ramos e a Cultura Política. 72I f. Tese (Doutorado em Teoria e Ciência da Comunicação). Escola de Comunicações e Artes, Universidade de São Paulo, São Paulo, 20I0.

SERRA BARROS. Viagem. Diário de Minas, Belo Horizonte, 27 fev. I955. Fundo Graciliano Ramos, Série Fortuna Crítica, Subsérie Matérias Extraídas de Periódicos, IEB/USP.

TÔRRES, Raquel Mundim. O inferno e o paraíso se confundem: viagens de brasileiros à URSS (I928-I933). I89 f. Dissertação (Mestrado em História). Instituto de Filosofia e Ciências Humanas, Universidade Estadual de Campinas, São Paulo, 2013.

VOLKOGONOV, Dmitri. Stalin: triunfo e tragédia. Trad. Joubert de Oliveira Brízida. Rio de Janeiro: Nova Fronteira, 2004. 